\title{
THE INTENSITY OF THE SIMULTANEOUS CONTRAST EFFECT DEPENDING ON THE CHANGE OF BACKGROUND LIGHTNESS
}

\author{
Krunoslav Hajdek, Ivan Budimir, Damir Vusić
}

Original scientific pape The paper explores the influence of the background effect of induction or simultaneous contrast on a specific type of media during the reproduction of a constructed design solution. The lightness of the background that surrounds the primary stimulus (rectangle) on a specifically constructed design was varied in ten ways. The intensity and direction of variations in the manifestation of lightness was determined with the help of the technique of simultaneous binocular harmonization on a certain number of respondents (10). The ANOVA analysis determined the existence of differences between arithmetic means $(F=132,50 ; p=0,000)$, and the post-hoc analysis by Fisher classified three groups of samples: samples on which simultaneous contrast reflects more strongly (a very dark background); samples on which the effect is weaker (a light background); and samples on which the effect is manifested in the opposite direction (a very bright background).

Keywords: achromatic reproduction; ANOVA; psychophysics; simultaneous contrast

Intenzitet efekta simultanog kontrasta u ovisnosti o promjeni svjetline pozadine

Izvorni znanstveni članak

U radu je istražen utjecaj pozadinskog efekta indukcije ili simultanog kontrasta na određenoj vrsti medija prilikom reprodukcije konstruiranog dizajnerskog rješenja. Pritom je na 10 načina varirana svjetlina pozadine koja okružuje primarni stimulus (pravokutnik) na specifično konstruiranom dizajnu. Utvrđen je intenzitet i smjer odstupanja u pojavnosti svjetline pomoću tehnike simultanog binokularnog usuglašavanja na određenom broju ispitanika (10). ANOVA analizom utvrđeno je postojanje razlika među aritmetičkim sredinama $(F=132,50 ; p=0,000)$ te su post-hoc analizom po Fisheru klasificirane tri grupe uzoraka: uzorci na kojima se simultani kontrast očituje jače (vrlo tamna pozadina); uzorci na kojima je efekt slabiji (svjetlija pozadina); te uzorci na kojima se efekt manifestira u suprotnom smjeru (vrlo svijetla pozadina).

Ključne riječi: akromatska reprodukcija; ANOVA; psihofizika; simultani kontrast

\section{Introduction}

Today, in the modern multimedia environment, an increasing number of innovative design solutions is required. The mentioned design solutions are by nature such that they could cause significant (adverse) problems in the process of transferring them in the "cross media" reproductive system. The mentioned problems and progress in the manifestation of colors is largely caused by the psychophysical visual effect of induction or simultaneous contrast that causes a shift in the manifestation of a color of a certain stimulus [1].

Psychophysics is a scientific discipline with an interest in exploring the perceptual reaction caused by a particular stimulus (the relationship between the stimulus and sensation) [1]. Thus, in graphic technology certain psychophysical methods examine shift in the manifestation of color. The mentioned methodology is very often applied in cross-media communication systems, which gives the possibility of defining the optimal conditions for the application of influencing parameters related to the design, reproduction, and creation of image files on graphic products in the circumstances of a potential manifestation of psychophysical visual effects [2]. Namely, the shift in the manifestation of color is a common perceptual phenomenon that occurs at each image graphic reproduction. Moreover, Richard O. Brown and Donald I. A. MacLeod are of the opinion that none of the colors of the objects in the visual field is perceived separately from the colors of all other objects [3]. Due to the effect of simultaneous contrast, if a gray sample is taken, and a white sample is put next to such gray sample, the color grey will look darker next to the white sample than the next to the black sample [4]. Simultaneous contrast or induction is often deliberately used in certain types of visual communications. For example, simultaneous contrast in visual arts occurs in the works of the famous Dutch painter Vincent van Gogh, as it can be seen on the painting The Cafe Terrace on the Place du Forum, which was created in Arles in $1888[5,6]$. On the mentioned painting, the effect of simultaneous contrast is the most pronounced in the places where two complementary colors meet. For example, the red color can on the painting be seen directly next to the green color, while the yellow color appears with the blue color, which creates a strong effect of simultaneous contrast.

Simultaneous contrast was first scientifically described by the French scientist Michel Eugène Chevreul in 1839 in his work De la Loi du Contraste Simultane des Couleurs [7]. After Chevreul's description, this effect became the subject of a number of interdisciplinary scientific studies aimed at determining the causes of this phenomenon $[8,9]$. It has been established that the effect of simultaneous contrast is more strongly manifested on objects of complementary colors [10]. The chromatic simultaneous contrast is based on localized chromatic adaptation $[11 \div 13]$. The relations between the simultaneous contrast and other effects, such as the Munker-White effect, have also been determined [11]. It has been proven that the chromatic simultaneous contrast and Munker-White effect have similar corresponding nonlinear characteristics [11, 12]. Different mathematical models that enable the calculation of the intensity and direction of the effect of simultaneous contrast have been made, such as the retinex theory [14] and the DOG and ODOG models [15]. The manifestations of this effect on graphic reproductions have also been examined, so as to 
achieve as efficient control of information on color in a cross-media information system as possible [16].

The goal of every visual psychophysical research is to identify and define a perceptually determined response of the test subject induced by the stimulus of precisely defined physical characteristics that are instrumentally measurable $[17,18]$. The paper presents the results of the research on the background psychophysical effect of induction or simultaneous contrast. The study determined the extent to which reproduced samples differ with respect to the predefined values of the color from the atlas. On the basis of the obtained results, the strength of the psychophysical visual effect of induction or simultaneous contrast for different variations of background lightness has been shown.

\section{Experimental part}

During the manifestation of psychophysical visual effects, determining the manifestation of color in communication systems is always based on the assessment of the psychophysical experience of one of the three (tone, saturation, and lightness) perceptual attributes of color that describe it $[19,20]$. The intensity of the effect is presented by calculated colorimetric color differences [18]. Psychophysical research primarily seeks to determine whether the respondent can detect a particular stimulus and compare it with another stimulus and describe the differences [21].

The experimental part of the research began with the preparation of a test sample that causes the manifestation of the effects of simultaneous contrast. The test sample for the evaluation of the effect of simultaneous contrast was derived in the following way. The sample was created as an achromatic figure (stimulus) that causes the effect of simultaneous contrast, the internal field has a value of $50 \%$ RTV of the color black (primary stimulus), while the external fields (which essentially represent the background, the secondary stimulus) have a value range from $0 \div 100 \%$ RTV of the color black in increments of $10 \%$ RTV from left to right (Fig. 1). The primary stimuli (internal squares) are on a press form deployed in such a way that the internal square is right above the separate zone of the ink tray, whereby the "empty" zone of the ink tray will be located between the two stimuli in order to prevent the influence of neighboring zones on the inking.

In that way, from the 23 available zones of the B2 format, all the even zones are empty, while vertically the lines with the stimuli are propagated to the sheet range. As part of the experiment, equivalent evaluation was done with the help of one of the five techniques for the visual evaluation of the relationship between the reproduction and the original, the technique of simultaneous binocular harmonization [22]. Respondents (10) had the task to assign to the primary stimulus on reproduction the fields from the color atlas that they perceived to be the most similar. Each respondent took the test 10 times, and what was measured was the arithmetic mean of Lab values assigned to the primary stimulus from the fields from the color atlas that were taken into account in further measurements. Printing was carried out on a calibrated machine for offset printing on a printing substrate for art printing (kunstdruck $140 \mathrm{~g} / \mathrm{m}^{2}$ ). The ambient conditions of the space for visual evaluation were compliant with the guidelines of the ISO 3664: 2009 norm $\left(10^{\circ}\right.$ viewing angle, $60 \mathrm{~cm}$ distance from observer to sample, matte gray environment and CIE D50 lighting). The evaluation of the effect, i.e. the tuning of test samples was conducted on a sample of 10 respondents, the average age of 23 years. The test form was printed on a calibrated machine for offset printing - Heidelberg Speedmaster SM 74-5-P by using the perceptual ICC rendering method. Rendering was done in Adobe Photoshop, where a transition from the Lab space of colors into the space of the colors of the profile for offset printing occurred. The Adobe (ACE) option was chosen as the conversion option, and a coated (kunstdruck) paper with a weight of $140 \mathrm{~g} / \mathrm{m}^{2}$ was used as a printing substrate. Before printing, the paper was conditioned in operation room for 48 hours in the standard ambient conditions (temperature of $23{ }^{\circ} \mathrm{C}$ and relative humidity of $55 \%$ ). The color atlas was made on a machine for the production of match prints, Espon Stylus Pro 4880, which was calibrated according to the curves for the calibration of a printing machine. The atlas was printed on the same type of printing substrate on which the impression was made. The atlas was made on the mentioned device in order for the comparison with the print to be as accurate as possible. Namely, in printing, in real conditions, such devices are used for the simulation of the print, and they ensure a very high accuracy between the reproduction obtained by printing on a printing press and by printing on the device for the reproduction of match prints. With this type of atlas in a range of 2,5\% RTV, a higher accuracy of the comparison on the correlation between the print and match print is acquired, than it is with the existing (standard) atlas (Munsell's) that does not have such fineness of the range between the fields. Precisely due to the created range of each field of $2,5 \%$, a greater accuracy of the atlas was obtained, and hence, when examining the differences between the acquired reproduction and the atlas, more accurate results can be obtained than when using standard atlases.The offset plate with the test form was manufactured by Kodak, and the plate type is Electra XD (thermal positive plate), with a spectral sensitivity from 800 to $850 \mathrm{~nm}$. The plate was made at a resolution of 175 lines and raster value of $2400 \mathrm{dpi}$ (AM raster), and the format of the plate is $745 \times 605 \mathrm{~cm}$. The device on which the offset plate was made is the platesetter Magnus Q800 Platesetter manufactured by Kodak. After the printing process, the first step is the visual comparison of the color atlas which was printed on the calibrated device for the production of match prints with a reproduction obtained according to the CIP3 values. The values of the internal fields on the impression were measured with the help of a spectrophotometer X Rite il pro, and they were visually compared with the fields on the color atlas on which the fields are designed so that each field has an increase in value of $2,5 \%$ RTV compared to the previous field, starting with the first field on the atlas that has a value of $2,5 \%$ RTV to the last field that has a value of $100 \%$ RTV (Fig. 2). After the visual evaluation and association of the corresponding fields from the color atlas with the primary stimuli on the reproductions obtained according to the CIP3 values, the CIE $L^{*} a^{*} b^{*}$ values on the atlas and the reproduction were measured. Furthermore, $\Delta \mathrm{L}^{*}$ 
and $\Delta E^{*}$ were also calculated. After that, deviations of the obtained values of test fields (stimuli) in relation to the CIP3 reference values (spectrophotometric analysis and conversion to CIE $\left.L^{*} a^{*} b^{*}\right)$ were calculated on the obtained samples.

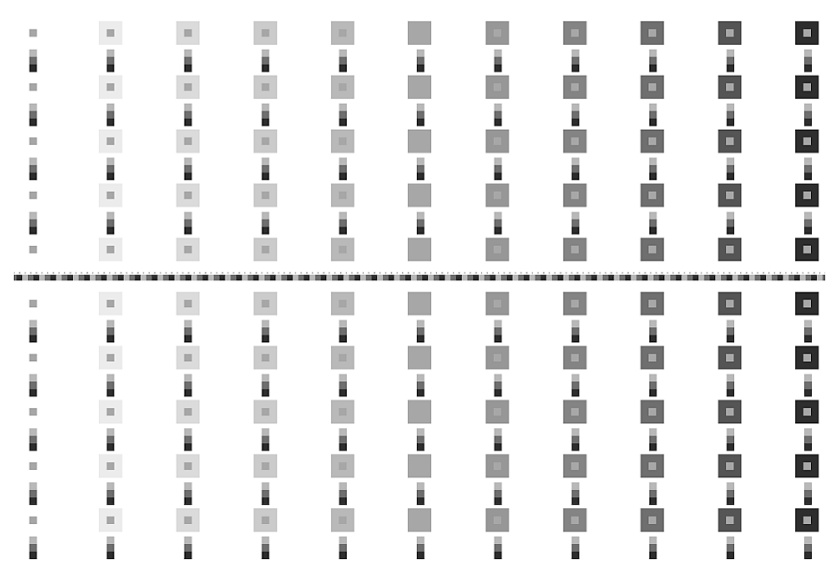

Figure 1 The design of the test form of the achromatic effect of simultaneous contrast

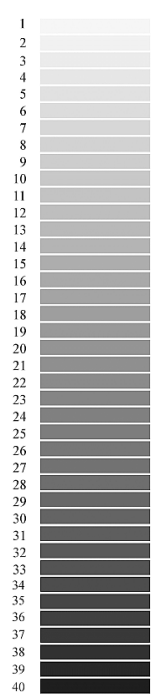

Figure 2 Color atlas with achromatic tones

The results of the research of Lab values calculated with the help of the $\Delta E_{00}$ formula, where:

$L^{\prime}=L^{*}$

$a^{\prime}=(1+G) \cdot a^{*}$,

$b^{\prime}=b^{*}$,

$C_{a b}^{\prime}=\left(a^{\prime 2}+b^{\prime 2}\right)^{0,5}$,

$h^{\prime}=\tan ^{-1}\left(\frac{b^{\prime}}{a^{\prime}}\right)$,

$G=0,5 \cdot\left[1-\left(\frac{\bar{C}_{a b}^{* 7}}{\bar{C}_{a b}^{* 7}+25^{7}}\right)^{0,5}\right]$,

where $\bar{C}_{a b}^{*}$ is the arithmetic mean of the $C_{a b}^{*}$ value for the pairs of samples

$$
\begin{aligned}
& \Delta L^{\prime}=L_{b}^{\prime}-L_{s}^{\prime}, \\
& \Delta C_{a b}^{\prime}=C_{a b, b}^{\prime}-C_{a b, s}^{\prime}, \\
& \Delta H^{\prime}{ }_{a b}=\left[2\left(C_{a b, b}^{\prime} C_{a b, s}^{\prime}\right)^{0,5} \sin \left(\frac{\Delta h_{a b}^{\prime}}{2}\right)\right],
\end{aligned}
$$

where the variables $b$ and $s$ refer to the comparison of samples and the standard sample, i.e.

$$
\begin{aligned}
& \Delta E_{00}=\left[\left(\frac{\Delta L^{\prime}}{k_{L} S_{L}}\right)^{2}+\left(\frac{\Delta C_{a b}^{\prime}}{k_{C} S_{C}}\right)^{2}+\left(\frac{\Delta H_{a b}^{\prime}}{k_{H} S_{H}}\right)^{2}+\right. \\
& \left.+R_{T}\left(\frac{\Delta C_{a b}^{\prime}}{k_{C} S_{C}}\right) \cdot\left(\frac{\Delta H_{a b}^{\prime}}{k_{H} S_{H}}\right)\right]^{0,5},
\end{aligned}
$$

where

$$
\begin{aligned}
& S_{L}=1+\frac{0,015 \cdot\left(\bar{L}^{\prime}-50\right)^{2}}{\left[20+\left(\bar{L}^{\prime}-50\right)^{2}\right]^{0,5}}, \\
& S_{C}=1+0,045 \cdot \bar{C}_{a b}^{\prime}, \\
& S_{H}=1+0,015 \cdot \bar{C}_{a b}^{\prime} \cdot T,
\end{aligned}
$$

where

$$
\begin{aligned}
& R_{T}=-\sin (2 \Delta \Theta) R_{C}, \\
& \Delta \Theta=30 \cdot \exp \left[-\left(\frac{\bar{h}_{a b}^{\prime}-275^{\circ}}{25}\right)^{2}\right] \\
& R_{C}=2 \cdot\left(\frac{\bar{C}_{a b}^{\prime 7}}{\bar{C}_{a b}^{\prime 7}+25^{7}}\right)^{0,5} .
\end{aligned}
$$

$\bar{L}^{\prime}, \bar{C}_{a b}^{\prime}, \bar{h}_{a b}^{\prime}$ are the arithmetic means of the pairs of samples, i.e. individual values.

\section{Research results}

Below are the results of the testing of the effect of achromatic induction (Tab. 3) on the primary stimulus (the internal square of lightness of $50 \%$ RTV), according to the 10 different variations of the background lightness of squares that surround the primary stimulus (Tab. 1, Tab. 2).

The results of the Tab. 1 indicate the existence of very small differences between the Lab values of the primary stimulus that could not have been avoided due to the technical characteristics of the printing device, the background that surrounds the primary stimulus. Namely, because the primary stimulus and background are in the same area of coloration, the increase of paint application on the background automatically increases the paint application on the primary stimulus. Because of that the tolerance among primary stimulus is set $<4$. 
Table 1 An overview of the Lab values of the primary stimulus

\begin{tabular}{|c|c|c|c|}
\hline Lightness & $L$ & $a$ & $b$ \\
\hline 10 & 61,00 & 0,50 & $-3,30$ \\
\hline 20 & 60,70 & 0,50 & $-3,30$ \\
\hline 30 & 60,00 & 0,50 & $-3,30$ \\
\hline 40 & 59,80 & 0,50 & $-3,30$ \\
\hline 50 & 59,20 & 0,50 & $-3,30$ \\
\hline 60 & 59,00 & 0,50 & $-3,30$ \\
\hline 70 & 58,70 & 0,50 & $-3,30$ \\
\hline 80 & 58,40 & 0,50 & $-3,30$ \\
\hline 90 & 58,10 & 0,50 & $-3,30$ \\
\hline 100 & 57,50 & 0,50 & $-3,30$ \\
\hline
\end{tabular}

Table 2 An overview of the Lab values of the backgrounds (secondary stimulus)

\begin{tabular}{|c|c|c|c|}
\hline Background & $L$ & $a$ & $b$ \\
\hline 10 & 82,7 & 0,8 & $-4,1$ \\
\hline 20 & 77,3 & 0,7 & $-3,9$ \\
\hline 30 & 71,8 & 0,5 & $-3,7$ \\
\hline 40 & 65,8 & 0,6 & $-3,3$ \\
\hline 50 & 56,8 & 0,4 & $-2,8$ \\
\hline 60 & 47,5 & 0,4 & $-2,3$ \\
\hline 70 & 39,6 & 0,4 & $-1,9$ \\
\hline 80 & 35,0 & 0,5 & $-1,2$ \\
\hline 90 & 28,2 & 0,8 & $-0,2$ \\
\hline 100 & 21,9 & 0,8 & 0,3 \\
\hline & & & \\
\hline
\end{tabular}

Table 3 An overview of the obtained values of colorimetric differences between the stimuli and the assigned fields from the color atlas

\begin{tabular}{|c|c|c|c|c|}
\hline Lightness & $\mathrm{d} E_{00}$ & $\mathrm{~d} L_{00}$ & $\mathrm{~d} C_{00}$ & $\mathrm{~d} H_{00}$ \\
\hline 10 & 1,22 & 1,14 & 0,15 & 0,42 \\
\hline 20 & 1,56 & 1,50 & 0,15 & 0,42 \\
\hline 30 & 1,93 & 1,87 & 0,15 & 0,42 \\
\hline 40 & 1,06 & $-0,96$ & 0,15 & 0,42 \\
\hline 50 & 0,92 & $-0,71$ & 0,16 & 0,57 \\
\hline 60 & 1,30 & $-1,15$ & 0,25 & 0,55 \\
\hline 70 & 1,95 & $-1,85$ & 0,25 & 0,55 \\
\hline 80 & 2,04 & $-1,95$ & 0,25 & 0,55 \\
\hline 90 & 2,13 & $-2,04$ & 0,25 & 0,55 \\
\hline 100 & 2,23 & $-2,15$ & 0,25 & 0,55 \\
\hline
\end{tabular}

Furthermore, Tab. 3 shows all values of colorimetric differences between the perception of the color of the stimuli and their physical values.

Below are the results of the statistical analysis that was conducted on the results of the experiment. The statistical analysis clearly indicates the existence of extremely noticeable regularities during the manifestation of the effect. Values $\Delta L_{00}$ are presented as positive or negative, depending on whether the assigned area from the color atlas is darker than the primary stimulus located on the reproduction obtained according to the CIP3 values, or on whether the assigned area is lighter than the primary stimulus.

\section{$4 \quad$ Discussion of research results}

A statistical analysis of all data obtained by the psychophysical visual experiment was carried out. To be more precise, what was analyzed were the value variations in lightness between the perceived and the physical lightness of the primary stimulus, i.e. the values of the variable $\Delta \mathrm{L} 00$. The mentioned analysis was carried out in the program STATISTICA 12 (StatSoft, Tulsa, USA). It consists of the calculation of the descriptive parameters of the differences in lightness, the Box and Whisher graphic display of results, the display of the results of the Kolmogorov-Smirnov test, and the results of ANOVA with repeated measures. A post-hoc analysis by Fisher was also carried out in order to identify the differences between arithmetic means

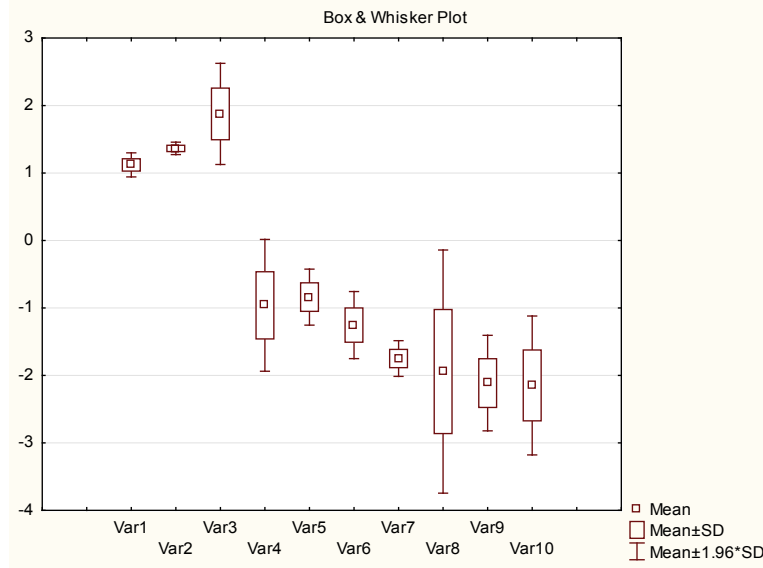

Figure 3 Box and Whisker plot of the experiment results

\subsection{Descriptive statistics}

A descriptive statistical analysis of the differences in lightness according to each respondent is shown in Tab. 4 the differences were calculated for 10 different variations of background lightness.

The results in Tab. 4 indicate a high accuracy of the results obtained by the experiment. Namely, the values of standard deviations and variances are very small for all samples. Furthermore, all ranges between the minimum and the maximum are very small.

A graphic Box and Whisker overview of arithmetic mean scores for each group is shown in Fig. 3.

Table 4 Descriptive statistics of the perceived difference in lightness (arithmetic mean \pm standard deviation $(\mu \pm \sigma)$, median (Med), mode (Mod), frequency of mode, minimum (Min), maximum (Max), variance (Var).

\begin{tabular}{|c|c|c|c|c|c|c|c|}
\hline \multirow{2}{*}{ Background lightness } & \multicolumn{9}{|c|}{ Descriptive statistics of differences in lightness } \\
\cline { 2 - 8 } & $\mu \pm \sigma$ & Med & Mod & Fr. Mod & Min & Max & Var \\
\hline 10 & $1,12 \pm 0,09$ & 1,05 & 1,05 & 6 & 1,05 & 1,23 & 0,01 \\
\hline 20 & $1,36 \pm 0,05$ & 1,36 & Multiple & 5 & 1,20 & 1,41 & 0,00 \\
\hline 30 & $1,88 \pm 0,38$ & 1,88 & Multiple & 5 & 1,51 & 2,24 & 0,15 \\
\hline 40 & $-0,96 \pm 0,50$ & $-0,96$ & Multiple & 4 & $-1,48$ & $-0,44$ & 0,25 \\
\hline 50 & $-0,84 \pm 0,21$ & $-0,71$ & $-0,71$ & 7 & $-1,15$ & $-0,71$ & 0,04 \\
\hline 60 & $-1,25 \pm 0,25$ & $-1,41$ & $-1,41$ & 7 & $-1,41$ & $-0,89$ & 0,06 \\
\hline 70 & $-1,75 \pm 0,13$ & $-1,85$ & $-1,85$ & 6 & $-1,85$ & $-1,59$ & 0,02 \\
\hline 80 & $-1,94 \pm 0,92$ & $-1,94$ & Multiple & 5 & $-2,81$ & $-1,07$ & 0,84 \\
\hline 90 & $-2,11 \pm 0,36$ & $-2,39$ & $-2,39$ & 6 & $-2,39$ & $-1,69$ & 0,13 \\
\hline 100 & $-2,15 \pm 0,53$ & $-2,15$ & Multiple & 4 & $-2,67$ & $-1,62$ & 0,28 \\
\hline
\end{tabular}




\subsection{ANOVA analysis for repeated measures}

Furthermore, the compliance of all the obtained data with the law of normal distribution was verified. For that purpose, the Kolmogorov-Smirnov test was applied, and the results are shown in Tab. 5.

Table 5 Results of the Kolmogorov-Smirnov test (Max D statistics, empirical $p$-value)

\begin{tabular}{|c|c|c|}
\hline Lightness & Max D & K-S $p$ \\
\hline 10 & 0,38 & $p<0,10$ \\
\hline 20 & 0,33 & $p<0,20$ \\
\hline 30 & 0,33 & $p<0,20$ \\
\hline 40 & 0,25 & $p>0,20$ \\
\hline 50 & 0,43 & $p<0,05$ \\
\hline 60 & 0,43 & $p<0,05$ \\
\hline 70 & 0,38 & $p<0,10$ \\
\hline 80 & 0,33 & $p<0,20$ \\
\hline 90 & 0,38 & $p<0,10$ \\
\hline 100 & 0,25 & $p>0,20$ \\
\hline
\end{tabular}

The Kolmogorov-Smirnov test confirmed the compliance of almost all variables with the normal distribution, which is a prerequisite for the implementation of the ANOVA analysis. To be more precise, the results of the experiment with the background lightness of the amounts $10,20,30,40,50,70,80$, and 100 are fully aligned with the normal distribution (Tab. 5). Furthermore, the results of the visual experiment with the lightness of 50 and 60 very slightly deviate from the normal distribution law.

Given that almost all variables are in line with the law of normal distribution, the ANOVA analysis with repeated measures was conducted. ANOVA analyzed the differences between the arithmetic means of the visual perception of the lightness of the primary stimulus for 10 different variations of lightness (Tab. 6), in order to determine the differences in the intensity of the effect of induction depending on different background lightness.

The post-hoc analysis by Fisher shows that the arithmetic means of differences in lightness $\left(\Delta L_{00}\right)$ statistically do not significantly differ with background lightness of 80, 90, and 100 (Tab. 7). Furthermore, groups whose background lightness is 40,50 , and 60 also do not significantly differ statistically. The same is with the groups with lightness of 10 and 20. Statistically significant differences between groups with background lightness of 70, 80, and 90 were also not identified. In all the remaining pairs, the arithmetic means also statistically do not differ significantly. The strongest intensity of the induction effect is achieved on a sample whose background lightness is 100 , where background is the darkest $\left(L_{100}=28,9\right)$. The arithmetic mean of the difference in lightness in the mentioned sample is $\mu_{100}=$ $-2,15$, while the median achieves the identical value $\operatorname{Med}_{100}=-2,15$. Induction intensity is a bit weaker on lightness samples with a slightly lighter background of 80 and $90\left(L_{80}=42,0\right.$ and $\left.L_{90}=35,2\right)$, with the arithmetic means of lightness differences of $\mu_{80}=-1,94$ and $\mu_{90}=$ $-2,11$ and medians $\operatorname{Med}_{80}=-1,94$ and $\operatorname{Med}_{80}=-2,39$. The arithmetic mean of the lightness difference in the group of background lightness of $70\left(L_{70}=46,6\right)$ is $\mu_{70}=$ $-1,75$, while the median is $\operatorname{Med}_{70}=-1,85$.
Table 6 Results of the ANOVA analysis (repeated measures)

\begin{tabular}{|c|c|c|c|c|c|}
\hline Effect & SS & $\begin{array}{r}\text { Degr. of } \\
\text { Freedom }\end{array}$ & MS & $F$ & $p$ \\
\hline R1 & 213,34 & 9 & 23,70 & 132,59 & 0,000 \\
\hline Error & 14,48 & 81 & 0,18 & & \\
\hline
\end{tabular}

It was determined that the corresponding $\mathrm{F}$-value is $F$ $=132,59$ with a statistical significance of the F-test that is $p=0,000<0,05$ (Tab. 6). Therefore, the previous test showed that there are statistically significant differences between the arithmetic means of the results of the visual experiment.

Furthermore, a post-hoc analysis by Fisher (Tab. 7) was also conducted in order to identify the groups whose arithmetic means statistically significantly differ $(p<$ $0,05)$.

Table 7 Results of the post-hoc analysis by Fisher Probabilities for Post Hoc Tests

\begin{tabular}{|c|c|c|c|c|c|c|c|c|c|}
\hline & \multicolumn{7}{|c|}{ Probabilities for Post Hoc Tests } \\
\hline Lightness & 10 & 20 & 30 & 40 & 50 & 60 & 70 & 80 & 90 \\
\hline 10 & - & & & & & & & & \\
\hline 20 & 0,20 & - & & & & & & & \\
\hline 30 & 0,00 & 0,00 & - & & & & & & \\
\hline 40 & 0,00 & 0,00 & 0,00 & - & & & & & \\
\hline 50 & 0,00 & 0,00 & 0,00 & 0,52 & - & & & & \\
\hline 60 & 0,00 & 0,00 & 0,00 & 0,12 & 0,03 & - & & & \\
\hline 70 & 0,00 & 0,00 & 0,00 & 0,00 & 0,00 & 0,01 & - & & \\
\hline 80 & 0,00 & 0,00 & 0,00 & 0,00 & 0,00 & 0,00 & 0,30 & - & \\
\hline 90 & 0,00 & 0,00 & 0,00 & 0,00 & 0,00 & 0,00 & 0,05 & 0,36 & - \\
\hline 100 & 0,00 & 0,00 & 0,00 & 0,00 & 0,00 & 0,00 & 0,03 & 0,28 & 0,85 \\
\hline
\end{tabular}

The effect of induction is also manifested on the samples of background lightness of 40,50 , and $60\left(L_{40}=\right.$ $71,8, L_{50}=63,8$ and $\left.L_{60}=54,5\right)$. On these samples the effect of induction is very small (Tab. 7). The arithmetic means of the aforementioned samples are on average $\mu_{40}$ $=-0,96, \mu_{50}=-0,84$ and $\mu_{60}=-1,25$. The medians of the aforementioned samples are $\operatorname{Med}_{40}=-0,96, \operatorname{Med}_{50}=$ $-0,71$ and $\operatorname{Med}_{60}=-1,41$.

On the samples of stronger background lightness of 10,20 , and $30\left(L_{10}=89,7, L_{20}=84,3, L_{30}=77,8\right)$, what has been noted is a modest shift of the manifestation of lightness that is of the opposite direction of the effect of induction. On these samples the primary stimulus is perceived as darker than its physical lightness. With background lightness of 10 , the arithmetic mean of the differences in lightness is $\mu_{10}=1,12$, while the median is $\operatorname{Med}_{10}=1,05$. With background lightness of 20, the arithmetic mean of the shift of lightness is $\mu_{20}=1,36$, while the median is the same $\operatorname{Med}_{20}=1,36$. With background lightness of 30 , the primary stimulus is perceived as the darkest, it is of the average intensity of $\mu_{30}=1,88$, and its median is $\operatorname{Med}_{30}=1,88$.

Namely, the previous results clearly indicate that the respondents, when assigning the appropriate fields from the color atlas to the primary stimuli on reproduction with the backgrounds of 10,20 , and 30 , assigned to them the darker fields from the atlas; while to the primary stimuli with the backgrounds of 40,50, 60, 70, 80, 90, and 100, they assigned the brighter fields of the color atlas. Thus, that means that they perceived the primary stimuli where the backgrounds are 10,20, and 30 as darker than the primary stimuli where the backgrounds are 40, 50, 60, 70, 80,90 , and 100; they perceived those stimuli as brighter 
with the exception of the primary stimulus with the background 50 , which blended with the background, and was perceived by the respondents similar to the background due to the fact that primary stimulus had 50 $\%$ of the application of color black, as it was the case with the background. The primary stimuli where the backgrounds are 40 and 60 also had a very small effect of induction because the applications of colors are quite similar to those on the primary stimulus. On the primary stimuli where the backgrounds are $70,80,90$, and 100 , the induction effect is manifested most strongly precisely because of the darker background in relation to the primary stimulus, where the darker background induces the stimulus, making it appear brighter than it actually is.

\section{Conclusion}

The paper presents results that clearly show the intensity and direction of a shift in the manifestation of lightness that happens due to the psychophysical visual effect of simultaneous contrast. This effect is manifested through a difference in the perception of the primary stimulus (the internal rectangle) with regard to the change in the lightness of the secondary stimuli (background). With the ANOVA analysis with repeated measures, that was conducted on the data obtained by a psychophysical visual experiment, it was found that there are differences between the arithmetic means of the differences between the perceived and physical lightness of the primary stimulus $(\mathrm{F}=132,59, p=0,000)$. A further post-hoc analysis by Fisher identified groups whose arithmetic means mutually differ. That is how three groups of samples were obtained. In the first group there are samples with background lightness of $70,80,90$, and 100 (very dark backgrounds). On those samples, the induction effect is most strongly manifested. The second group includes samples with background lightness of 40, 50, and 60. On those samples, a very small induction effect is manifested. In the third group are the samples of background lightness of 10,20, and 30 (very bright backgrounds). On those samples, a shift occurs in the opposite direction.

It can be seen from the presented results that lightness $\Delta \mathrm{L} 00$ on the primary stimuli with backgrounds 10,20 , and 30 goes in one direction; while on the primary stimuli with backgrounds $40,50,60,70,80,90$, and 100, it goes in the opposite direction. Namely, where the respondents assigned darker fields from the color atlas to the primary stimuli on reproduction (backgrounds 10, 20, and 30), on those stimuli lightness $\Delta L_{00}$ goes in the positive direction, and on those primary stimuli where the respondents assigned brighter fields from the color atlas, $\Delta L_{00}$ goes in the negative direction. When it comes to the values of $\Delta E_{00}$, they increase on fields with backgrounds 10,20 , and 30 , while on the primary stimulus with the background 40 , the value of $\Delta E_{00}$ decreases, and on the primary stimuli with the background 50 , it decreases to the lowest value precisely due to the fact that the background is almost identical to the value of the primary stimulus that is $50 \%$ of the color black. On the primary stimulus with the background 60 , the value of $\Delta E_{00}$ begins to increase, and it does so all the way to the primary stimulus where the background is 100 and it reaches it top value, and with it is the effect of induction the most pronouced in areas where backgrounds are 60, 70, 80, 90, and 100.

From the presented results, it can be seen that the effect of the psychophysical visual effect of induction or simultaneous contrast, as described in the paper, is through the primary stimulus manifested as darker on a lighter background, while it is manifested as lighter on a darker background, even though it is of unchanged color application as a design solution.

The background psychophysical effect of induction may in a larger number of instances occur in the printing process as a result of certain design solutions as their "undesirable" consequence of conveying information in "cross-media" reproductive systems. It most often manifests itself during bleed printing (margin) or during the printing of banners in a book block. Namely, with the aforementioned design solutions when operators in the printing process need to print such a design solution, it comes to their application of the method of tuning in the printing process, which results in the unevenness of the final print. The unevenness of the print occurs precisely because of the distorted perceptions of the colors of operators, which is the result of the manifestation of the induction effect. Operators, in a large number of instances, during the manifestation of the induction effect on the primary stimulus on a bright background, increase the color, and on a dark background they decrease the color, which is why the final result has an uneven print.

The described methodology has great possibilities of application on further research of other psychophysical visual effects.

\section{References}

[1] Lukaček, M.; Milković, M.; Hajdek, K.. Analiza manifestacije McCollough efekta u Cross-Media reprodukcijskim sustavima. // Technical Journal. 7, 2(2013), pp. 170-176.

[2] Milković, M.; Vusić, D.; Mrvac, N. Percepcija boje u crossmedia komunikacijskim sustavima. // Printing and Design. (2012), pp. 27-34

[3] Creutzfeldt, O.; Ito, M. Functional synaptic organization of primary visual cortex neurons in the cat. // Experimental Brain Research. 6(1968), pp. 324-352. DOI: 10.1007/BF00233183

[4] Bressan, P. Explaining lightness illusions. // Perception. 30, (2001), pp. 1031-1046. DOI: 10.1068/p3109

[5] Cernea, P. The simultaneous contrast of the colors in Van Gogh paints. // Oftalmologia. 55, 4(2002), pp. 96-100.

[6] Sjraar van Heugten. Van Gogh and the Colors of the Night, Amsterdam, 2009.

[7] Michel Eugène Chevreul. De la loi du contraste simultané des couleurs et de l'assortiment des objets colorés considéré d'après cette loi dans ses rapports avec la peinture, les tapisseries des Gobelins, les tapisseries de Beauvais pour meubles, les tapis, la mosaïque, les vitraux colorés, l'impression des étoffes, l'imprimerie, l'enluminure, la décoration des édifices, l'habillement et l'horticulture, Paris, 1839.

[8] Adelson, E. H. Lightness Perception and Lightness Illusions. In The New Cognitive Neurosciences, $2^{\text {nd }}$ ed., $M$. Gazzaniga, ed. Cambridge, MA: MIT Press, 2000, pp. 339351. 
[9] Adelson, E. H. Perceptual organization and the judgment of brightness. // Science. 262, (1993), pp. 2042-2044. DOl: 10.1126/science.8266102

[10] Hazel, Rossotti. Colour, Why the World Isn't Grey, Princeton University Press, Princeton, NJ, 1985, pp. 135136.

[11] Brenner, E. Cornelissen, F.W.; Spatial interactions in color vision depend on distances between boundaries, Naturwissenschaften, 78. Springer Verlag 1991.

[12] Hong, S. W.; Shevell, S. K. Brightness contrast and assimilation from patterned inducing backgrounds. // Vision Research. 44, (2004), pp. 35-43. DOl: 10.1016/j.visres.2003.07.010

[13] Norton, T. T.; Corliss, D. A.; Bailey, J. E. The Psychophysical Measurement of Visual Function, Butterworth-Heinemann, Woburn, Massachusetts, 2002.

[14] Land, E. H.; Mccann, J. J. Lightness and retinex theory. // J. Opt. Soc. Amer. 61, (1971), pp. 1-11. DOI: 10.1364/JOSA.61.000001

[15] Judith, A. McArthur; Bernard, Moulden. A twodimensional model of brightness perception based on spatial filtering consistent with retinal processing. // Vision Research. 39, 6(1999), pp. 1199-1219. DOI: 10.1016/S00426989(98)00216-8

[16] Matijević, M.; Mrvac, N.; Mikota, M. Efekt proširivanja i simultanog kontrasta kod modificiranih figural dotted i groundal dotted iluzija. // Tehnicki vjesnik-Technical Gazette. 21, 6(2014), pp. 1297-1301.

[17] Devlin, A. K. Perceptual fidelity for digital image display, Ph.D. thesis, Faculty of Engineering, Department of Computer Science to the University of Bristol, 2004.

[18] Wu, R. C.; Wardman, R. H.; Luo, M. R. A Comparison of Lightness Contrast Effects in CRT and Surface Colours. // Color Research and Application. 30, (2004), pp. 13-20. DOI: 10.1002/col.20074

[19] Vusić, D.; Mrvac, N.; Milković, M. The neon color spreading effect in various surround ambient conditions. // Tehnicki vjesnik-Technical Gazette. 18, 2(2011), pp. 219225.

[20] Malacara, D. Color Vision and Colorimetry: Theory and Applications, Spie Press, Washington, 2002.

[21] Milković, M. Evaluacija odnosa psihofizikalnih determiniranih efekata i metoda prevođenja gamut, Ph.D. thesis, Zagreb, 2006.

[22] Milković, M.; Mrvac, N.; Vusić, D. Vizualna psihofizika i dizajn, Polytechnic of Varaždin, Varaždin, 2009.

\section{Authors' addresses:}

Krunoslav Hajdek, dipl. ing. graf. tehn. University North

104. brigade 3, 42000 Varaždin, Croatia

E-mail: krunoslav.hajdek@unin.hr

Dr. sc. Ivan Budimir

Faculty of Graphic Arts

Getaldićeva 2, 10000 Zagreb, Croatia

E-mail: ivan.budimir@grf.hr

Dr. sc. Damir Vusić dipl. ing. graf. tehn. University North

104. brigade 3, 42000 Varaždin, Croatia

E-mail: damir.vusic@unin.hr 